\title{
Suppression of Fast Proton Conduction by Dilution of a Hydronium Solvate lonic Liquid: Localization of Ligand Exchange
}

\section{$\operatorname{AUTHOR}(S)$ :}

Kawata, Kio; Kitada, Atsushi; Tsuchida, Naoki; Saimura, Masayuki; Nagata, Takashi; Katahira, Masato; Fukami, Kazuhiro; Murase, Kuniaki

\section{CITATION:}

Kawata, Kio ... [et al]. Suppression of Fast Proton Conduction by Dilution of a Hydronium Solvate Ionic Liquid: Localization of Ligand Exchange. Journal of the Electrochemical Society 2020, 167(4): 046508.

\section{ISSUE DATE:}

2020

URL:

http://hdl.handle.net/2433/255861

\section{RIGHT:}

This is the Accepted Manuscript version of an article accepted for publication in Journal of the Electrochemical Society. The Electrochemical Society and IOP Publishing Ltd are not responsible for any errors or omissions in this version of the manuscript or any version derived from it. The Version of Record is available online at https://doi.org/10.1149/19457111/ab75fc:; この論文は出版社版でありません。引用の際には出版社版をご確認ご利用ください。; This is not the published version. Please cite only the published version. 
Suppression of Fast Proton Conduction by Dilution of a Hydronium Solvate Ionic

\section{Liquid: Localization of Ligand Exchange}

Kio Kawata, ${ }^{1}$ Atsushi Kitada, ${ }^{1, z}$ Naoki Tsuchida, ${ }^{1}$ Masayuki Saimura, ${ }^{2}$ Takashi Nagata, ${ }^{2}$

Masato Katahira, ${ }^{2}$ Kazuhiro Fukami, ${ }^{1, *}$ and Kuniaki Murase ${ }^{1, *}$

${ }^{1}$ Department of Materials Science and Engineering, Kyoto University, Sakyo-ku, Kyoto 606-8501, Japan

${ }^{2}$ Institute of Advanced Energy, Kyoto University, Gokasho, Uji, Kyoto 611-0011, Japan

*Electrochemical Society Member.

${ }^{z}$ E-mail: kitada.atsushi.3r@kyoto-u.ac.jp 


\section{ABSTRACT}

A dilution effect on the proton conduction of a hydronium solvate ionic liquid $\left[\mathrm{H}_{3} \mathrm{O}^{+} \cdot 18 \mathrm{C} 6\right] \mathrm{Tf}_{2} \mathrm{~N}$, which consists of hydronium ion $\left(\mathrm{H}_{3} \mathrm{O}^{+}\right)$, 18-crown-6-ether ligand (18C6), and bis[(trifluoromethyl)sulfonyl]amide anion $\left(\mathrm{Tf}_{2} \mathrm{~N}^{-} ; \mathrm{Tf}=\mathrm{CF}_{3} \mathrm{SO}_{2}\right)$, has been studied. When $\left[\mathrm{H}_{3} \mathrm{O}^{+} \cdot 18 \mathrm{C} 6\right] \mathrm{Tf}_{2} \mathrm{~N}$ was diluted using equimolar $18 \mathrm{C} 6$ solvent, the distinctive fast proton conduction in $\left[\mathrm{H}_{3} \mathrm{O}^{+} \cdot 18 \mathrm{C} 6\right] \mathrm{Tf}_{2} \mathrm{~N}$ was suppressed in stark contrast to the case of common protic ionic liquids. Nuclear magnetic resonance spectroscopy showed that the fast exchange between free 18C6 molecules and coordinated ones, suggesting that the added solvent had induced a local proton exchange rather than a cooperative proton relay. 
Ionic liquids (ILs) consist only of cations and anions and melt below $100{ }^{\circ} \mathrm{C}$, which is an ultimate form of highly concentrated electrolyte solutions. They have increasingly attracted attention owing to their various uses as media for chemical, biochemical, and electrochemical reactions. ${ }^{1-6}$ Among ILs, solvate ILs are often prepared through neutralization of Lewis acidic metal salts and Lewis basic oligoethers (glymes), where metal cations are solvated by an equimolar amount of solvents, or ligands, to give complex cations. In contrast, protic ILs are prepared through neutralization of Brønsted acids and bases, which are preferred as acid-catalyzed reaction media and fuel cell electrolytes because of the presence of acidic protons. ${ }^{3-6}$

Recently, we reported a hydronium $\left(\mathrm{H}_{3} \mathrm{O}^{+}\right)$solvate IL that is classified as both a solvate IL and protic IL. The hydronium solvate IL $\left[\mathrm{H}_{3} \mathrm{O}^{+} \cdot 18 \mathrm{C} 6\right] \mathrm{Tf}_{2} \mathrm{~N}(18 \mathrm{C} 6=18$-crown-6-ether; $\left.\mathrm{Tf}=\mathrm{SO}_{2} \mathrm{CF}_{3}\right)$ is not only the first example of a nonmetal-cation-solvate IL but also the protic IL achieving the record of the strongest Brønsted acidity among ILs. ${ }^{7}$ In this IL, the hydronium $\left(\mathrm{H}_{3} \mathrm{O}^{+}\right)$ion (i.e., solute ion) is solvated by $18 \mathrm{C} 6$ ligand (i.e., solvent) to form a $\left[\mathrm{H}_{3} \mathrm{O}^{+} \cdot 18 \mathrm{C} 6\right]$ complex cation (i.e., solvate), and the counter anion is the $\mathrm{Tf}_{2} \mathrm{~N}^{-}$ anion. 
While common protic ILs show Grotthuss-like proton conduction upon dilution, i.e., in the presence of free neutral molecules, an anomalous proton conduction has also been reported in the hydronium solvate $\mathrm{IL}\left[\mathrm{H}_{3} \mathrm{O}^{+} \cdot 18 \mathrm{C} 6\right] \mathrm{Tf}_{2} \mathrm{~N}$, where the protons of $\mathrm{H}_{3} \mathrm{O}^{+}$move faster than the $18 \mathrm{C} 6$ ligand. $^{8}$ This was the first observation of ligand exchange conduction without free neutral molecules, among not only solvate ILs but also protic ILs. ${ }^{8-12}$ Lithium-based highly concentrated electrolytes have been widely studied in recent years. ${ }^{13-20}$ In some of them, Grotthuss-like fast ion conduction without free ligands has been observed. ${ }^{19,20}$ In the $\mathrm{LiBF}_{4}$ and sulfolane system, for example, $\mathrm{Li}^{+}$ions move faster than ligands or solvent molecules, although the fast lithium conduction is suppressed by solvent addition or dilution. ${ }^{19}$ Likewise, it is interesting to study whether the dilution of $\left[\mathrm{H}_{3} \mathrm{O}^{+} \cdot 18 \mathrm{C} 6\right] \mathrm{Tf}_{2} \mathrm{~N}$ by $18 \mathrm{C} 6$ solvent would suppress the fast proton conduction or accelerate it, as well as the dilution of common protic ILs. Additionally, study on the hydronium-based electrolytes attracts interest from the viewpoint of recently-proposed hydronium ion batteries. ${ }^{21,22}$

In this work, the conduction mechanism of a diluted, or solvent-added hydronium solvate IL, i.e., $\left[\mathrm{H}_{3} \mathrm{O}^{+} \cdot(18 \mathrm{C} 6)_{2}\right] \mathrm{Tf}_{2} \mathrm{~N}$, has been studied in detail. ${ }^{1} \mathrm{H}$ and ${ }^{19} \mathrm{~F}$ pulsed-field gradient 
spin echo nuclear magnetic resonance (PGSE-NMR) measurements were performed to determine the self-diffusion coefficients of $\mathrm{H}_{3} \mathrm{O}^{+}, 18 \mathrm{C} 6$ ligand, and $\mathrm{Tf}_{2} \mathrm{~N}^{-}$anion of the diluted hydronium solvate IL.

\section{Experimental}

Materials. 18-crown-6-ether (18C6; Kanto Chemical, 99\% purity) and bis(trifluoromethylsulfonyl)imide $\left(\mathrm{HTf}_{2} \mathrm{~N}\right.$; Kanto Chemical, 99\% purity) were used without further purification. Ultrapure water was prepared using a Merck Milli-Q Reference A system.

Synthesis of $\left[\mathrm{H}_{3} \mathrm{O}^{+} \cdot(18 \mathrm{C} 6)_{2}\right] \mathrm{Tf}_{2} \mathrm{~N}$. A hydronium solvate IL $\left[\mathrm{H}_{3} \mathrm{O}^{+} \cdot 18 \mathrm{C} 6\right] \mathrm{Tf}_{2} \mathrm{~N}$ was synthesized as follows. Water $(0.360 \mathrm{~g}, 30 \mathrm{mmol})$ and $\mathrm{HTf}_{2} \mathrm{~N}(5.623 \mathrm{~g}, 20 \mathrm{mmol})$ were mixed and stirred at $400 \mathrm{rpm}$ at room temperature (RT) for $1 \mathrm{~h}$. Then, $18 \mathrm{C} 6(5.286 \mathrm{~g}, 20$ mmol) was added and the mixture was stirred at $400 \mathrm{rpm}$ at $90{ }^{\circ} \mathrm{C}$ for $2.5 \mathrm{~h}$ before vacuum-drying at $\mathrm{RT}$ for $2 \mathrm{~h}$ to obtain $\left[\mathrm{H}_{3} \mathrm{O}^{+} \cdot 18 \mathrm{C} 6\right] \mathrm{Tf}_{2} \mathrm{~N} .18 \mathrm{C} 6(5.286 \mathrm{~g}, 20 \mathrm{mmol})$ was added to $\left[\mathrm{H}_{3} \mathrm{O}^{+} \cdot 18 \mathrm{C} 6\right] \mathrm{Tf}_{2} \mathrm{~N}$ and stirred at $400 \mathrm{rpm}$ at $50{ }^{\circ} \mathrm{C}$ for $2 \mathrm{~h}$ for dilution. 
Characterization of $\left[\mathrm{H}_{3} \mathrm{O}^{+} \cdot(18 \mathrm{C6})_{2}\right] \mathrm{Tf}_{2} \mathrm{~N}$. The glass transition temperature of the resulting $\left[\mathrm{H}_{3} \mathrm{O}^{+} \cdot(18 \mathrm{C} 6)_{2}\right] \mathrm{Tf}_{2} \mathrm{~N}$ IL was determined using a differential scanning calorimeter (DSC; Rigaku, DSC8231) with the sweeping rate of $5{ }^{\circ} \mathrm{C} \mathrm{min}^{-1}$.

For Raman spectroscopic measurements, an integrated Raman system (B\&W Tek, InnoRam 785), consisting of a semiconductor laser light source $(785 \mathrm{~nm})$, an axial transmissive spectrograph, a holographic probe head, and a CCD detector, was used. Raman spectra for $\left[\mathrm{H}_{3} \mathrm{O}^{+} \cdot(18 \mathrm{C} 6)_{2}\right] \mathrm{Tf}_{2} \mathrm{~N}$ were obtained at $\mathrm{RT}$, for $\left[\mathrm{H}_{3} \mathrm{O}^{+} \cdot 18 \mathrm{C} 6\right] \mathrm{Tf}_{2} \mathrm{~N}$ at $75{ }^{\circ} \mathrm{C}$, and for pure $18 \mathrm{C} 6$ at $60{ }^{\circ} \mathrm{C}$. Infrared (IR) spectroscopic measurements were performed at RT using a JASCO FT/IR-460 plus system. Here, $\left[\mathrm{H}_{3} \mathrm{O}^{+} \cdot(18 \mathrm{C} 6)_{2}\right] \mathrm{Tf}_{2} \mathrm{~N}$ was directly put on the barium fluoride window, while $\left[\mathrm{H}_{3} \mathrm{O}^{+} \cdot 18 \mathrm{C} 6\right] \mathrm{Tf}_{2} \mathrm{~N}$ or pure $18 \mathrm{C} 6$ was mixed with Nujol and hexachlorobutadiene and painted on the barium fluoride window. A set of nuclear magnetic resonance (NMR) spectra, i.e., ${ }^{1} \mathrm{H},{ }^{13} \mathrm{C}$, and ${ }^{19} \mathrm{~F}$ NMR spectra, were obtained at $600 \mathrm{MHz}$ at $60{ }^{\circ} \mathrm{C}$ using a JNM-ECA600 FT NMR spectrometer (JEOL Ltd.). The use of a double NMR tube, purchased from Shigemi Corp. (Catalog NO. SC002), prevented the sample from mixing with the external standard. Traces of dimethyl 
sulfoxide- $d_{6}$ (Cambridge Isotope Laboratories, Inc.) were placed in the outer tube (5.2 $\mathrm{mm} \phi)$ and $\left[\mathrm{H}_{3} \mathrm{O}^{+} \cdot(18 \mathrm{C} 6)_{2}\right] \mathrm{Tf}_{2} \mathrm{~N}$ was added to the internal tube $(5.0 \mathrm{~mm} \phi)$. The PGSENMR measurements were also performed at 60 and $75^{\circ} \mathrm{C}$ using the same equipment. The self-diffusion coefficients of each component in $\left[\mathrm{H}_{3} \mathrm{O}^{+} \cdot(18 \mathrm{C} 6)_{2}\right] \mathrm{Tf}_{2} \mathrm{~N}$ were measured using a simple Hahn spin echo sequence and analyzed using the Stejskal equation; $\ln \left(I / I_{0}\right)$ $=-D(\gamma g \delta)^{2}(\Delta-\delta / 3)$, where $I$ is the echo signal intensity, $I_{0}$ is the initial echo signal intensity, $D$ is the self-diffusion coefficient, $\gamma$ is the gyromagnetic ratio $\left(2.67515 \times 10^{8} \mathrm{rad}\right.$ $\mathrm{s}^{-1} \mathrm{~T}^{-1}$ for ${ }^{1} \mathrm{H}$ and $2.51716 \times 10^{8} \mathrm{rad} \mathrm{s}^{-1} \mathrm{~T}^{-1}$ for $\left.{ }^{19} \mathrm{~F}\right), g$ is the amplitude of the gradient pulses, $\delta$ is the duration of the gradient pulses, and $\Delta$ is the interval between the leading edges of the gradient pulses. ${ }^{23}$ The $g$ values used were in the range $20-280 \mathrm{mT} \mathrm{m}^{-1}$ at both temperatures, $\delta$ was $8 \mathrm{~ms}$, and the value of $\Delta$ was $100 \mathrm{~ms}$.

The conductivity of the electrolyte was determined by electrochemical impedance spectroscopy (Bio-Logic Science Instruments SAS, VSP-300) using stainless steel electrodes. The cell constant was calibrated with 0.1 and $1 \mathrm{~mol} \mathrm{dm}^{-3} \mathrm{KCl}$ aqueous solutions. The measurement was carried out in a thermostatic chamber (Espec Co., SU222 ) in the temperature range of 10 to $90{ }^{\circ} \mathrm{C}$. Viscosity measurements were performed in 
the same temperature range as conductivity measurements using a viscometer (Kyoto Electronics Manufacturing Co., Ltd., EMS-1000). Using the measured values of weight and volume, density was calculated to be $1.15 \mathrm{~g} \mathrm{~cm}^{-3}$.

Thermal gravimetric analysis (TGA) was conducted for $\left[\mathrm{H}_{3} \mathrm{O}^{+} \cdot(18 \mathrm{C} 6)_{2}\right] \mathrm{Tf}_{2} \mathrm{~N}$, $\left[\mathrm{H}_{3} \mathrm{O}^{+} \cdot 18 \mathrm{C} 6\right] \mathrm{Tf}_{2} \mathrm{~N}$, pure $18 \mathrm{C} 6$, and the equimolar mixture of $\mathrm{HTf}_{2} \mathrm{~N}$ and $\mathrm{H}_{2} \mathrm{O}$ $\left(\mathrm{HTf}_{2} \mathrm{~N} \cdot \mathrm{H}_{2} \mathrm{O}\right)$ with the sweeping rate of $5{ }^{\circ} \mathrm{C} \min ^{-1}$, using Rigaku Thermo plus Evo-2 TG-DTA8122 instrument in dry air atmosphere. Metallic aluminum pans were used for $\left[\mathrm{H}_{3} \mathrm{O}^{+} \cdot(18 \mathrm{C} 6)_{2}\right] \mathrm{Tf}_{2} \mathrm{~N}, \quad\left[\mathrm{H}_{3} \mathrm{O}^{+} \cdot 18 \mathrm{C} 6\right] \mathrm{Tf}_{2} \mathrm{~N}$, and pure $18 \mathrm{C} 6$, and alumina pan for $\mathrm{HTf}_{2} \mathrm{~N} \cdot \mathrm{H}_{2} \mathrm{O} .10 \mathrm{mg}$ sample was placed on the pan and alumina powder was used as a standard.

\section{Results and Discussion}

Synthesis of $\left[\mathrm{H}_{3} \mathrm{O}^{+} \cdot(18 \mathrm{C} 6)_{2}\right] \mathrm{Tf}_{2} \mathrm{~N}$. The equimolar mixture of $18 \mathrm{C} 6$ and $\left[\mathrm{H}_{3} \mathrm{O}^{+} \cdot 18 \mathrm{C} 6\right] \mathrm{Tf}_{2} \mathrm{~N}$ was a colorless liquid at RT. Table I shows the chemical analysis data for H, C, N, F, and $\mathrm{S}$, which were consistent with the suggested formulation $\left[\mathrm{H}_{3} \mathrm{O}^{+} \cdot(18 \mathrm{C} 6)_{2}\right] \mathrm{Tf}_{2} \mathrm{~N}$, within $\pm 0.2 \mathrm{wt} \%$ of the calculated value. The $\mathrm{H}_{2} \mathrm{O}$ content of the complex was $2.15 \mathrm{wt} \%$, as 
analyzed by Karl-Fischer coulometric titration, and in good agreement with the calculated value of $2.18 \mathrm{wt} \%$. These quantitative analysis results support that the complex was 18C6: $\mathrm{H}_{2} \mathrm{O}: \mathrm{HTf}_{2} \mathrm{~N}=2: 1: 1$ by mole.

Figure 1 displays the DSC curves for $\left[\mathrm{H}_{3} \mathrm{O}^{+} \cdot(18 \mathrm{C} 6)_{2}\right] \mathrm{Tf}_{2} \mathrm{~N}$. The glass transition occurred at $-55^{\circ} \mathrm{C}$ and there was no melting point. Since the melting point for $\left[\mathrm{H}_{3} \mathrm{O}^{+} \cdot 18 \mathrm{C} 6\right] \mathrm{Tf}_{2} \mathrm{~N}$ is $68-70{ }^{\circ} \mathrm{C},{ }^{7}$ this glass transition was caused because of dilution with $18 \mathrm{C} 6$.

Characterization of $\left[\mathrm{H}_{3} \mathrm{O}^{+} \cdot(18 \mathrm{C6})_{2}\right] \mathrm{Tf}_{2} \mathrm{~N}$. Figure 2 shows a set of Raman spectra, where $\left[\mathrm{H}_{3} \mathrm{O}^{+} \cdot(18 \mathrm{C} 6)_{2}\right] \mathrm{Tf}_{2} \mathrm{~N}$ displayed a peak at $875 \mathrm{~cm}^{-1}$ that indicated a change in the COC stretching and $\mathrm{CH}_{2}$ rocking modes of $18 \mathrm{C} 6$ as a result of complex formation, similar to the case of $\left[\mathrm{H}_{3} \mathrm{O}^{+} \cdot 18 \mathrm{C} 6\right] \mathrm{Tf}_{2} \mathrm{~N}$ and alkali metal ether complexes. ${ }^{7,24-30} \mathrm{~A}$ broad band between 750 and $850 \mathrm{~cm}^{-1}$ were observed in both $\left[\mathrm{H}_{3} \mathrm{O}^{+} \cdot 18 \mathrm{C} 6\right] \mathrm{Tf}_{2} \mathrm{~N}$ and $\left[\mathrm{H}_{3} \mathrm{O}^{+} \cdot(18 \mathrm{C} 6)_{2}\right] \mathrm{Tf}_{2} \mathrm{~N}$. According to Bühl et al., the computed Raman bands for $\left[\mathrm{H}_{3} \mathrm{O}^{+} \cdot 18 \mathrm{C} 6\right]$ complex between $800 \mathrm{~cm}^{-1}$ and $900 \mathrm{~cm}^{-1}$ appear at $\mathrm{B} 1\left(860 \mathrm{~cm}^{-1}\right), \mathrm{B} 2(828$ $\mathrm{cm}^{-1}$,), B3 $\left(810 \mathrm{~cm}^{-1}\right.$, ) and B4 $\left(803 \mathrm{~cm}^{-1}\right)$, with the peak ratio 22:1:3:6. ${ }^{31}$ We believe that the $\mathrm{B} 1$ band corresponds to a band centered at around $875 \mathrm{~cm}^{-1}$ and the other bands to a single broad band between 780 and $850 \mathrm{~cm}^{-1}$, and these area ratio, estimated by Gaussian curve fitting (see Figure $2 b)$, is 1:0.54 $(=22:(1+3+6))$, which agrees the computed result. Therefore, the broad band in $\left[\mathrm{H}_{3} \mathrm{O}^{+} \cdot 18 \mathrm{C} 6\right] \mathrm{Tf}_{2} \mathrm{~N}$ does not belong to free $18 \mathrm{C} 6$ but to 
$\left[\mathrm{H}_{3} \mathrm{O}^{+} \cdot 18 \mathrm{C} 6\right]$ complex. On the other hand, in $\left[\mathrm{H}_{3} \mathrm{O}^{+} \cdot(18 \mathrm{C} 6)_{2}\right] \mathrm{Tf}_{2} \mathrm{~N}$, the ratio of a band centered at around $875 \mathrm{~cm}^{-1}$ to a broad band between 750 and $850 \mathrm{~cm}^{-1}$ is $1: 2.2$, much larger than 1:0.54. The larger value resulted not only from bound $\left[\mathrm{H}_{3} \mathrm{O}^{+} \cdot(18 \mathrm{C} 6)\right]$ complex but also from free 18C6, evidencing the presence of "free" $18 \mathrm{C} 6$ molecules in $\left[\mathrm{H}_{3} \mathrm{O}^{+} \cdot(18 \mathrm{C} 6)_{2}\right] \mathrm{Tf}_{2} \mathrm{~N}$. In order to conduct more quantitative analysis, Raman measurements of $\left[\mathrm{H}_{3} \mathrm{O}^{+}(18 \mathrm{C} 6)_{n}\right] \mathrm{Tf}_{2} \mathrm{~N}$ with $1<n<2$ are necessary, which are our future works. Notably, in both $\left[\mathrm{H}_{3} \mathrm{O}^{+} \cdot(18 \mathrm{C} 6)_{2}\right] \mathrm{Tf}_{2} \mathrm{~N}$ and $\left[\mathrm{H}_{3} \mathrm{O}^{+} \cdot 18 \mathrm{C} 6\right] \mathrm{Tf}_{2} \mathrm{~N}$, the bands for $\mathrm{Tf}_{2} \mathrm{~N}^{-}$ anions centered at $741 \mathrm{~cm}^{-1}$ had no shoulder peaks and exhibited a similar full width of half maximum (fwhm) compared to our previous report, ${ }^{32}$ indicating that the $\mathrm{Tf}_{2} \mathrm{~N}^{-}$anions were "free" and not present as complex anions such as $\left[\mathrm{H}\left(\mathrm{Tf}_{2} \mathrm{~N}\right)_{2}\right]^{-33}$

The $v_{1}-v_{4}$ bands in Fig. 3 a proved the existence of $\mathrm{H}_{3} \mathrm{O}^{+}$; these characteristic bands readily established the presence of $\mathrm{H}_{3} \mathrm{O}^{+}$with $18 \mathrm{C} 6 .{ }^{34,35}$ The $v_{1}$ and $v_{3}$ stretching modes gave a very broad band centered at $2880 \mathrm{~cm}^{-1}$, which overlapped with the sharper maximum at $2880 \mathrm{~cm}^{-1}$ arising from the $\mathrm{C}-\mathrm{H}$ stretching motions of $18 \mathrm{C} 6$. The $v_{4}$ band at $1650 \mathrm{~cm}^{-1}$ was attributed to the bending mode and the band at $2200 \mathrm{~cm}^{-1}$ was the first harmonic of $v_{2}$, i.e., the symmetric bending mode. The $v_{2}$ band at $1100 \mathrm{~cm}^{-1}$ was not clearly observed because of overlapping with a strong band from 18C6.

The formation of $\left[\mathrm{H}_{3} \mathrm{O}^{+} \cdot 18 \mathrm{C} 6\right]$ was not clearly observed in the IR spectra (see Fig. 3b). In our previous results, the COC stretching absorption for pure $18 \mathrm{C} 6$ was also seen as a 
broad band at $1125 \mathrm{~cm}^{-1}$, which disappeared and split into sharp bands at 1138 and 1091 $\mathrm{cm}^{-1}$ because of $\left[\mathrm{H}_{3} \mathrm{O}^{+} \cdot 18 \mathrm{C} 6\right]$ formation. ${ }^{7,34}$ In the case of $\left[\mathrm{H}_{3} \mathrm{O}^{+} \cdot(18 \mathrm{C} 6)_{2}\right] \mathrm{Tf}_{2} \mathrm{~N}$, the absorptions for both pure $18 \mathrm{C} 6$ and $\left[\mathrm{H}_{3} \mathrm{O}^{+} \cdot 18 \mathrm{C} 6\right]$ overlapped.

These Raman and IR results strongly suggest that $\left[\mathrm{H}_{3} \mathrm{O}^{+} \cdot(18 \mathrm{C} 6)_{2}\right] \mathrm{Tf}_{2} \mathrm{~N}$ consists of $\left[\mathrm{H}_{3} \mathrm{O}^{+} \cdot 18 \mathrm{C} 6\right], \mathrm{Tf}_{2} \mathrm{~N}^{-}$, and free $18 \mathrm{C} 6$ in the liquid state. Therefore, $\left[\mathrm{H}_{3} \mathrm{O}^{+} \cdot(18 \mathrm{C} 6)_{2}\right] \mathrm{Tf}_{2} \mathrm{~N}$ is a concentrated acid solution with free solvents rather than a hydronium solvate IL, based on the determination of the solvate IL. ${ }^{24}$

The following NMR results support the results of chemical analysis, DSC, Raman, and IR measurements; although the results of ${ }^{1} \mathrm{H}$ and ${ }^{13} \mathrm{C}$ NMR for a different sample of $\left[\mathrm{H}_{3} \mathrm{O}^{+} \cdot(18 \mathrm{C} 6)_{2}\right] \mathrm{Tf}_{2} \mathrm{~N}$ were reported previously, ${ }^{8}$ those for the present sample are given in this article: The ${ }^{1} \mathrm{H}$ NMR spectrum (Fig. 4a) showed only two signals at 11.23 and 3.22 ppm, corresponding to $\mathrm{H}_{3} \mathrm{O}^{+}$and $\mathrm{CH}_{2}$ of $18 \mathrm{C} 6$, respectively. The peak area ratio was $1: 16$, which was in good agreement with the theoretical proton ratio for $\mathrm{H}_{3} \mathrm{O}^{+}$and two $18 \mathrm{C} 6$ (or $\mathrm{C}_{24} \mathrm{H}_{48} \mathrm{O}_{12}$ ). The signal for $\mathrm{H}_{3} \mathrm{O}^{+}$in $\left[\mathrm{H}_{3} \mathrm{O}^{+} \cdot(18 \mathrm{C} 6)_{2}\right] \mathrm{Tf}_{2} \mathrm{~N}$ was shifted to a lower magnetic field than that in the spectrum of $\left[\mathrm{H}_{3} \mathrm{O}^{+} \cdot 18 \mathrm{C} 6\right] \mathrm{Tf}_{2} \mathrm{~N}$. This indicated that the addition of $18 \mathrm{C} 6$ changed the chemical environment of $\mathrm{H}_{3} \mathrm{O}^{+}$to a more positive charge. 
The ${ }^{13} \mathrm{C}$ NMR spectrum (Fig. 4b) displayed a singlet for the $18 \mathrm{C} 6$ ligands (69.75 ppm) and a quartet for $\mathrm{CF}_{3}$ of $\mathrm{Tf}_{2} \mathrm{~N}^{-}$anions (122.96, 120.83, 118.69 and 116.55 ppm; peak area ratio of $1: 3: 3: 1)$ with a peak area ratio of $12: 1$, which agreed with the theoretical ${ }^{13} \mathrm{C}$ ratio of two $18 \mathrm{C} 6$ to $\mathrm{Tf}_{2} \mathrm{~N}^{-}$, i.e., $\mathrm{C}_{24} \mathrm{H}_{48} \mathrm{O}_{12}:\left(\mathrm{CF}_{3} \mathrm{SO}_{2}\right)_{2} \mathrm{~N}=24: 2$. The results of ${ }^{1} \mathrm{H}$ and ${ }^{13} \mathrm{C} \mathrm{NMR}$ measurements suggest that free and bound 18C6 could not be detected independently within the NMR measurement timescale.

In Fig. $4 \mathrm{c},{ }^{19} \mathrm{~F}$ NMR spectrum exhibited a singlet at $-79.57 \mathrm{ppm}$. In the case of pure $\mathrm{HTf}_{2} \mathrm{~N}$, its signal for ${ }^{19} \mathrm{~F}$ appeared at $-76.0 \mathrm{ppm} .{ }^{36}$ This indicates that ${ }^{19} \mathrm{~F}$ for $\left[\mathrm{H}_{3} \mathrm{O}^{+} \cdot 18 \mathrm{C} 6\right] \mathrm{Tf}_{2} \mathrm{~N}$ was more negatively charged than that for pure $\mathrm{HTf}_{2} \mathrm{~N}$, and that the precursor $\mathrm{HTf}_{2} \mathrm{~N}$ was not included in $\left[\mathrm{H}_{3} \mathrm{O}^{+} \cdot(18 \mathrm{C} 6)_{2}\right] \mathrm{Tf}_{2} \mathrm{~N}$.

Self-diffusion coefficients. Figures 5a and 5b show the plots of echo signal attenuation on the basis of the Stejskal equation for $18 \mathrm{C} 6$ (red circles), $\mathrm{Tf}_{2} \mathrm{~N}^{-}$(blue circles), and $\mathrm{H}_{3} \mathrm{O}^{+}$ (black circles) of $\left[\mathrm{H}_{3} \mathrm{O}^{+} \cdot(18 \mathrm{C} 6)_{2}\right] \mathrm{Tf}_{2} \mathrm{~N}$ at 60 and $75^{\circ} \mathrm{C}$. As shown, the plots had a linear relationship. According to the Stejskal equation, the gradients of the fitted lines are proportional to the diffusion coefficients. Table II lists the estimated values of self- 
diffusion coefficients for $\left[\mathrm{H}_{3} \mathrm{O}^{+} \cdot(18 \mathrm{C} 6)_{2}\right] \mathrm{Tf}_{2} \mathrm{~N}$ and $\left[\mathrm{H}_{3} \mathrm{O}^{+} \cdot 18 \mathrm{C} 6\right] \mathrm{Tf}_{2} \mathrm{~N}$. For $\left[\mathrm{H}_{3} \mathrm{O}^{+} \cdot(18 \mathrm{C} 6)_{2}\right] \mathrm{Tf}_{2} \mathrm{~N}$, the diffusion coefficient of $\mathrm{H}_{3} \mathrm{O}^{+}$was almost the same as those of $18 \mathrm{C} 6$ and $\mathrm{Tf}_{2} \mathrm{~N}^{-}$. Consequently, $\mathrm{H}_{3} \mathrm{O}^{+}$moved as fast as $18 \mathrm{C} 6$ and $\mathrm{Tf}_{2} \mathrm{~N}^{-}$in $\left[\mathrm{H}_{3} \mathrm{O}^{+} \cdot(18 \mathrm{C} 6)_{2}\right] \mathrm{Tf}_{2} \mathrm{~N}$, while $\mathrm{H}_{3} \mathrm{O}^{+}$moved 1.5 times faster than $18 \mathrm{C} 6$ and $\mathrm{Tf}_{2} \mathrm{~N}^{-}$in $\left[\mathrm{H}_{3} \mathrm{O}^{+} \cdot 18 \mathrm{C} 6\right] \mathrm{Tf}_{2} \mathrm{~N}$. In other words, the fast proton conduction of the hydronium solvate IL was suppressed by dilution. Notably, the self-diffusion coefficients of $18 \mathrm{C} 6$ and $\mathrm{Tf}_{2} \mathrm{~N}^{-}$ for $\left[\mathrm{H}_{3} \mathrm{O}^{+} \cdot(18 \mathrm{C} 6)_{2}\right] \mathrm{Tf}_{2} \mathrm{~N}$ at $60{ }^{\circ} \mathrm{C}$ were quite similar to those for $\left[\mathrm{H}_{3} \mathrm{O}^{+} \cdot 18 \mathrm{C} 6\right] \mathrm{Tf}_{2} \mathrm{~N}$ at $75{ }^{\circ} \mathrm{C}$, and of $\left[\mathrm{H}_{3} \mathrm{O}^{+} \cdot(18 \mathrm{C} 6)_{2}\right] \mathrm{Tf}_{2} \mathrm{~N}$ at $75{ }^{\circ} \mathrm{C}$ were quite similar to those of $\left[\mathrm{H}_{3} \mathrm{O}^{+} \cdot 18 \mathrm{C} 6\right] \mathrm{Tf}_{2} \mathrm{~N}$ at $85^{\circ} \mathrm{C}$. In the case of common protic ILs, ${ }^{10-12}$ the Grotthuss-like conduction of $\mathrm{H}^{+}$is promoted by dilution, while ligands move faster when they are added to common solvate ILs. ${ }^{24}$ Consequently, in terms of the effect of dilution, the hydronium solvate IL is distinguished not only from protic ILs but also from the previously reported solvate ILs.

Walden plot. A plot of molar conductivity $\left(\Lambda_{\mathrm{imp}} / \mathrm{S} \mathrm{cm}^{2} \mathrm{~mol}^{-1}\right)$ vs. fluidity $\left(\eta^{-1} / \mathrm{Poise}^{-1}\right)$, i.e., the Walden plot, is displayed in Fig. 6 . The molar conductivity $\Lambda_{\text {imp }}$ of the solution is 
defined as follows; $\Lambda_{\text {imp }}=M \sigma / d$, where $\sigma$ is the conductivity measured by the electrochemical impedance method, $d$ is density of $\left[\mathrm{H}_{3} \mathrm{O}^{+} \cdot(18 \mathrm{C} 6)_{2}\right] \mathrm{Tf}_{2} \mathrm{~N}\left(1.15 \mathrm{~g} \mathrm{~cm}^{-3}\right)$, and $M$ is molecular weight $\left(827.8 \mathrm{~g} \mathrm{~mol}^{-1}\right)$. The ionicity on the basis of Walden plot is expressed as $\Lambda_{\text {imp }} / \Lambda_{\text {ideal }}$, where both $\Lambda_{\text {imp }}$ and $\Lambda_{\text {ideal }}$ are the molar conductivities. ${ }^{37}$ The molar conductivity, $\Lambda_{\text {ideal }}$, is the ideal molar conductivity at a given fluidity $\left(\eta^{-1}\right)$ of an ideal $\mathrm{KCl}$ aqueous solution. In other words, the absolute value of $\Lambda_{\text {ideal }}$ is equal to that of $\eta^{-1}$. The values of $\Delta W=\log \left(\Lambda_{\text {imp }} / \Lambda_{\text {ideal }}\right)$, the vertical difference from the $\mathrm{KCl}$ ideal line in the Walden plot, were -0.33 at $60^{\circ} \mathrm{C}$ and -0.34 at $75^{\circ} \mathrm{C}$, resulting in $\Lambda_{\text {imp }} / \Lambda_{\text {ideal }}=0.46$ at both temperatures. Note that although the ionicity had been regarded as the degree of cation-anion dissociation, ${ }^{38}$ the understanding of the ionicity of ionic liquids is further deepened. ${ }^{39}$

Temperature dependence of $\eta$ and $\sigma$. Figure 9 shows the temperature dependence of viscosity $(\eta / \mathrm{mPa} s)$ and ionic conductivity $\left(\sigma / \mathrm{S} \mathrm{cm}^{-1}\right)$ of $\left[\mathrm{H}_{3} \mathrm{O}^{+} \cdot(18 \mathrm{C} 6)_{2}\right] \mathrm{Tf}_{2} \mathrm{~N}$ in the temperature range of 10 to $90{ }^{\circ} \mathrm{C}$. As these plots showed convex-curved profiles, the temperature-dependent conductivity and viscosity could be fitted using the empirical 
Vogel-Fulcher-Tamman (VFT) equation; $\sigma=\sigma_{0} \exp \left[-B T_{0} /\left(T-T_{0}\right)\right]$ for conductivity and $\eta$ $=\eta_{0} \exp \left[B T_{0} /\left(T-T_{0}\right)\right]$ for viscosity, where $\sigma_{0}, \eta_{0}, B$, and $T_{0}$ are adjustable parameters. ${ }^{40}$ These fitting parameters are listed in Table III. The VFT-type parameters of viscosity and ionic conductivity were similar, indicating that the temperature dependence of viscosity dominated that of ionic conductivity.

Dilution effect for the hydronium solvate IL. Table IV summarizes the viscosities and conductivities of $\left[\mathrm{H}_{3} \mathrm{O}^{+} \cdot(18 \mathrm{C} 6)_{2}\right] \mathrm{Tf}_{2} \mathrm{~N}\left(\right.$ at 60 and $75^{\circ} \mathrm{C}$ ) and $\left[\mathrm{H}_{3} \mathrm{O}^{+} \cdot 18 \mathrm{C} 6\right] \mathrm{Tf}_{2} \mathrm{~N}$ (at 75 and $\left.85^{\circ} \mathrm{C}\right)$. Comparing these values of $\left[\mathrm{H}_{3} \mathrm{O}^{+} \cdot(18 \mathrm{C} 6)_{2}\right] \mathrm{Tf}_{2} \mathrm{~N}$ at $60{ }^{\circ} \mathrm{C}$ with those of $\left[\mathrm{H}_{3} \mathrm{O}^{+} \cdot 18 \mathrm{C} 6\right] \mathrm{Tf}_{2} \mathrm{~N}$ at $85^{\circ} \mathrm{C}$, it was evident that the conductivity of the latter was 1.5 times that of the former, while both had similar viscosities. On the other hand, conductivities of both $\left[\mathrm{H}_{3} \mathrm{O}^{+} \cdot(18 \mathrm{C} 6)_{2}\right] \mathrm{Tf}_{2} \mathrm{~N}$ and $\left[\mathrm{H}_{3} \mathrm{O}^{+} \cdot 18 \mathrm{C} 6\right] \mathrm{Tf}_{2} \mathrm{~N}$ were almost the same at $75{ }^{\circ} \mathrm{C}$, while the viscosity of the former was about half that of the latter and each diffusion coefficient of $\mathrm{H}_{3} \mathrm{O}^{+}, 18 \mathrm{C} 6$, and $\mathrm{Tf}_{2} \mathrm{~N}^{-}$at $75{ }^{\circ} \mathrm{C}$ in $\left[\mathrm{H}_{3} \mathrm{O}^{+} \cdot(18 \mathrm{C} 6)_{2}\right] \mathrm{Tf}_{2} \mathrm{~N}$ was larger than that in $\left[\mathrm{H}_{3} \mathrm{O}^{+} \cdot 18 \mathrm{C} 6\right] \mathrm{Tf}_{2} \mathrm{~N}$, as shown in Table II. The higher conductivity of $\left[\mathrm{H}_{3} \mathrm{O}^{+} \cdot 18 \mathrm{C} 6\right] \mathrm{Tf}_{2} \mathrm{~N}$ compared to that of $\left[\mathrm{H}_{3} \mathrm{O}^{+} \cdot(18 \mathrm{C} 6)_{2}\right] \mathrm{Tf}_{2} \mathrm{~N}$ was a result of the faster proton conduction in 
the former.

The ionicity, expressed as $\Lambda_{\mathrm{imp}} / \Lambda_{\mathrm{NMR}}$, was also estimated by means of impedance and PGSE-NMR measurements, where both $\Lambda_{\text {imp }}$ and $\Lambda_{\mathrm{NMR}}$ are molar conductivities. The molar conductivity, $\Lambda_{\mathrm{imp}}$, of the solution is defined as above. The molar conductivity $\Lambda_{\mathrm{NMR}}$ is given by the Nernst-Einstein equation, $\Lambda_{\mathrm{NMR}}=F^{2} / R T\left(D_{\mathrm{H}_{3} \mathrm{O}^{+}}+D_{\mathrm{Tf}_{2} \mathrm{~N}^{-}}\right)$, where $F$ is Faraday constant, $R$ is the gas constant, $T$ is the absolute temperature, and $D_{\mathrm{H}_{3} \mathrm{O}^{+}}$and $D_{\mathrm{Tf}_{2} \mathrm{~N}^{-}}$ are the self-diffusion coefficients of $\mathrm{H}_{3} \mathrm{O}^{+}$and $\mathrm{Tf}_{2} \mathrm{~N}^{-}$, respectively, measured by PGSENMR. ${ }^{25}$ Table V lists the calculated ionicities for $\left[\mathrm{H}_{3} \mathrm{O}^{+} \cdot(18 \mathrm{C} 6)_{2}\right] \mathrm{Tf}_{2} \mathrm{~N}$ at 60 and $75{ }^{\circ} \mathrm{C}$. Table $\mathrm{V}$ also summarizes the proton transference numbers at 60 and $75{ }^{\circ} \mathrm{C}$ using $D_{\mathrm{H}_{3} \mathrm{O}^{+}}$ and $D_{\mathrm{Tf}_{2} \mathrm{~N}^{-}}$. According to Harris, ${ }^{41}$ the use of equation $t_{\mathrm{H}_{3} \mathrm{O}^{+}}=\left(D_{\mathrm{H}_{3} \mathrm{O}^{+}} / D_{\mathrm{H}_{3} \mathrm{O}^{+}}+D_{\mathrm{Tf}_{2} \mathrm{~N}^{-}}\right)$is at best an alternative way of saying one species diffuses more rapidly than the other. While $\mathrm{H}_{3} \mathrm{O}^{+}$apparently diffuses faster than $\mathrm{Tf}_{2} \mathrm{~N}^{-}$in $\left[\mathrm{H}_{3} \mathrm{O}^{+} \cdot 18 \mathrm{C} 6\right] \mathrm{Tf}_{2} \mathrm{~N}$ because transference number is more than 0.5 , it is likely that $\mathrm{H}_{3} \mathrm{O}^{+}$moves as fast as $\mathrm{Tf}_{2} \mathrm{~N}^{-}$because $t_{\mathrm{H}_{3} \mathrm{O}^{+}}$is nearly equal to 0.5 in $\left[\mathrm{H}_{3} \mathrm{O}^{+} \cdot(18 \mathrm{C} 6)_{2}\right] \mathrm{Tf}_{2} \mathrm{~N}$.

It has been shown that the diffusion coefficients of $\mathrm{H}_{3} \mathrm{O}^{+}$and $18 \mathrm{C} 6$ are almost the same in $\left[\mathrm{H}_{3} \mathrm{O}^{+} \cdot(18 \mathrm{C} 6)_{2}\right] \mathrm{Tf}_{2} \mathrm{~N}$. We propose, however, that this conduction mechanism is 
different from the "ordinary" vehicle mechanism. Given an ordinary vehicle mechanism in $\left[\mathrm{H}_{3} \mathrm{O}^{+} \cdot(18 \mathrm{C} 6)_{2}\right] \mathrm{Tf}_{2} \mathrm{~N}, \mathrm{H}_{3} \mathrm{O}^{+}$and two $18 \mathrm{C} 6$ ligands would be bound to form a sandwich complex and move together. A possibility of a $18 \mathrm{C} 6-\mathrm{H}_{3} \mathrm{O}^{+}-18 \mathrm{C} 6$ sandwich complex, however, can be rejected because a sandwich complex of $\mathrm{H}_{3} \mathrm{O}^{+}$between two crown ether ligands is formed only when the crown ether has a smaller cavity than that of $18 \mathrm{C} 6 .{ }^{34}$ The TGA results also deny the possibility of this sandwich complex (see Figure 8). Given 2 to 1 sandwich complexes in $\left[\mathrm{H}_{3} \mathrm{O}^{+} \cdot(18 \mathrm{C} 6)_{2}\right] \mathrm{Tf}_{2} \mathrm{~N}$, the hydronium ion would form hydrogen bonds with two oxygens of one 18C6 ligand and with one oxygen of the other 18C6, as well as the real sandwich complex. ${ }^{34}$ The hydrogen bonds of the sandwich complexes should be weaker than $\left[\mathrm{H}_{3} \mathrm{O}^{+} \cdot 18 \mathrm{C} 6\right] \mathrm{Tf}_{2} \mathrm{~N}$, and the weight loss of TGA for $\left[\mathrm{H}_{3} \mathrm{O}^{+} \cdot(18 \mathrm{C} 6)_{2}\right] \mathrm{Tf}_{2} \mathrm{~N}$ would start at much lower temperature. We found, however, that the TGA curves are similar to each other (see Figs. 8a and 8b). We also speculate that the COC Raman band would not be similar to that of $\left[\mathrm{H}_{3} \mathrm{O}^{+} \cdot 18 \mathrm{C} 6\right] \mathrm{Tf}_{2} \mathrm{~N}$ due to weaker coordination if such sandwich complex were exist in $\left[\mathrm{H}_{3} \mathrm{O}^{+} \cdot(18 \mathrm{C} 6)_{2}\right] \mathrm{Tf}_{2} \mathrm{~N}$. The value of fwhm of the band in $\left[\mathrm{H}_{3} \mathrm{O}^{+} \cdot(18 \mathrm{C} 6)_{2}\right] \mathrm{Tf}_{2} \mathrm{~N}$ is actually $17.9 \pm 0.4$, similar to that of $\left[\mathrm{H}_{3} \mathrm{O}^{+} \cdot 18 \mathrm{C} 6\right] \mathrm{Tf}_{2} \mathrm{~N}(16.5 \pm 0.3)$. 
Since the NMR and Raman results proved that the free and bound 18C6 molecules exchange very fast, protons make round trips between the two $18 \mathrm{C} 6$ in this system. In fact, the fwhm value of the ${ }^{1} \mathrm{H}$ NMR signals of $18 \mathrm{C} 6$ in $\left[\mathrm{H}_{3} \mathrm{O}^{+} \cdot(18 \mathrm{C} 6)_{2}\right] \mathrm{Tf}_{2} \mathrm{~N}(0.0108$ at $\left.60{ }^{\circ} \mathrm{C}\right)$ was approximately $25 \%$ of $\left[\mathrm{H}_{3} \mathrm{O}^{+} \cdot 18 \mathrm{C} 6\right] \mathrm{Tf}_{2} \mathrm{~N}\left(0.0414\right.$ at $\left.75^{\circ} \mathrm{C}\right)$, even though the viscosity of the former $\left(33.9 \mathrm{mPa} \mathrm{s}\right.$ at $\left.60^{\circ} \mathrm{C}\right)$ was about $80 \%$ of the latter $(42.9 \mathrm{mPa} \mathrm{s}$ at $\left.75^{\circ} \mathrm{C}\right)$. Thus, the narrow signals of $\left[\mathrm{H}_{3} \mathrm{O}^{+} \cdot(18 \mathrm{C} 6)_{2}\right] \mathrm{Tf}_{2} \mathrm{~N}$ were attributable to the faster ligand exchange of chemical states caused by the "localized exchange". Consequently, we propose that the added solvents induce local proton exchange (i.e., round trip of protons) rather than promoting a cooperative proton relay of the hydronium solvate IL.

\section{Conclusions}

In this work, the physicochemical properties of an equimolar mixture of solvent and hydronium solvate ionic liquid, $\left[\mathrm{H}_{3} \mathrm{O}^{+} \cdot(18 \mathrm{C} 6)_{2}\right] \mathrm{Tf}_{2} \mathrm{~N}$, were studied. While protons of $\mathrm{H}_{3} \mathrm{O}^{+}$moved faster than $18 \mathrm{C} 6$ ligands in $\left[\mathrm{H}_{3} \mathrm{O}^{+} \cdot 18 \mathrm{C} 6\right] \mathrm{Tf}_{2} \mathrm{~N}$, the addition of the $18 \mathrm{C} 6$ solvent suppressed the fast proton conduction. The NMR spectroscopy results showed that as the free 18C6 ligands and coordinated ones underwent fast exchange in the diluted 
sample, the proton exchange became localized between the neighboring $18 \mathrm{C} 6$ ligands and terminated the cooperative proton relay of $\left[\mathrm{H}_{3} \mathrm{O}^{+} \cdot 18 \mathrm{C} 6\right] \mathrm{Tf}_{2} \mathrm{~N}$. The protonic properties of $\left[\mathrm{H}_{3} \mathrm{O}^{+} \cdot(18 \mathrm{C} 6)_{n}\right] \mathrm{Tf}_{2} \mathrm{~N}$ with $1<n<2$ are of special interest. Identification and rationalization of proton transfer in a series of concentrated $\mathrm{H}_{3} \mathrm{O}^{+}-18 \mathrm{C} 6$ electrolytes can provide the guidelines for designing new electrolyte systems.

\section{Acknowledgments}

This work was supported financially by Grants-in-Aid for Scientific Research (B) (No.19H02490: A. K.) from the Japan Society for the Promotion of Science. A. K. also thanks the Joint Usage/Research Program on Zero-Emission Energy Research, Institute of Advanced Energy, Kyoto University (ZE31A-1).

\section{ORCID}

Atsushi Kitada https://orcid.org/0000-0002-4387-8687

Takashi Nagata https://orcid.org/000-0002-3733-2709

Masato Katahira https://orcid.org/000-0003-0336-7660 
Kazuhiro Fukami https://orcid.org/0000-0001-9120-5578

Kuniaki Murase https://orcid.org/0000-0002-7564-9416 


\section{References}

1. T. Welton, Chem. Rev., 99, 2071 (1999).

2. K. Fujita, K. Murata, M. Masuda, N. Nakamura, and H. Ohno, RSC Adv., 2, 4018 (2012).

3. T. L. Greaves and C. J. Drummond, Chem. Rev., 115, 11379 (2015).

4. P. A. Hunt, C. R. Ashworth, and R. P. Matthews, Chem. Soc. Rev., 44, 1257 (2015).

5. M. Armand, F. Endres, D. R. MacFarlane, H. Ohno, and B. Scrosati, Nat. Matter, 8, 621 (2009).

6. A. S. Amarasekara, Chem. Rev., 116, 6133 (2016).

7. A. Kitada, S. Takeoka, K. Kintsu, K. Fukami, M. Saimura, T. Nagata, M. Katahira, and K. Murase, J. Electrochem. Soc., 165, H121 (2018).

8. A. Kitada, S. Takeoka, K. Kintsu, K. Fukami, M. Saimura, T. Nagata, M. Katahira, and K. Murase, J. Electrochem. Soc., 165, H496 (2018).

9. K. Yoshida, M. Nakamura, Y, Kazue, N. Tachikawa, S. Tsuzuki, S. Seki, K. Dokko, and M. Watanabe, J. Am. Chem. Soc., 133, 13121 (2011).

10. Md. A. B. H. Susan, A. Noda, S. Mitsushima, and M. Watanabe, Chem. Commun., 
938 (2003).

11. A. Noda, Md. A. B. H. Susan, K. Kudo, S. Mitsushima, K. Hayamizu, and M. Watanabe, J. Phys. Chem. B, 107, 4024 (2003).

12. H. Doi, X. Song, B. Minofar, R. Kanzaki, T. Takamuku, and Y. Umebayashi, Chem. Eur. J., 19, 11522 (2013).

13. L. Suo, Y. S. Hu, H. Li, M. Armand, and L. Chen, Nat. Commun., 4, No. 1481 (2013).

14. Y. Yamada, K. Furukawa, K. Sodeyama, K. Kikuchi, M. Yaegashi, Y. Tateyama, and A. Yamada, J. Am. Chem. Soc., 136, 5039, (2014).

15. Y. Yamada, K. Usui, C. H. Chiang, K. Kikuchi, K. Furukawa, and A. Yamada, ACS Appl. Mater. Interfaces, 6, 10892 (2014).

16. J. Qian, W. A. Henderson, W. Xu, P. Bhattacharya, M. Engelhard, O. Borodin, and J. G. Zhang, Nat. Commun., 6, 6362 (2015).

17. Y. Yamada and A. Yamada, Chem. Lett., 46, 1056 (2017).

18. M. Watanabe, K. Dokko, K. Ueno, M. L. Thomas, Bull. Chem. Soc. Jpn., 1660 (2018).

19. K. Dokko, D. Watanabe, Y. Ugata, M. L. Thomas, S. Tsuzuki, W. Shinoda, K. Hashimoto, K. Ueno, Y. Umebayashi, and M. Watanabe, J. Phys. Chem. B, 122, 10736 
(2018).

20. S. Kondou, M. L. Thomas, T. Mandai, K. Ueno, K. Dokko, and M. Watanabe, Phys. Chem. Chem. Phys., 21, 5097 (2019).

21. X. Wang, C. Bommier, Z. Jian, Z. Li, R. S. Chandrabose, I. A. Rodríguez-Pérez, P. A. Greaney, and X. Ji, Angew. Chem. Int. Ed., 56, 2909 (2017).

22. Y. Zhu, X. Yang, and X. Zhang, Angew. Chem. Int. Ed., 56, 6378 (2017).

23. E. O. Stejskal and J. E. Tanner, J. Chem. Phys., 42, 288 (1965).

24. T. Mandai, K. Yoshida, K. Ueno, K. Dokko, and M. Watanabe, Phys. Chem. Chem. Phys., 16, 8761 (2014).

25. K. Ueno, K. Yoshida, M. Tsuchiya, N. Tachikawa, K. Dokko, and M. Watanabe, J. Phys. Chem. B, 116, 11323 (2012).

26. T. Mandai, S. Tsuzuki, K. Ueno, K. Dokko, and M. Watanabe, Phys. Chem. Chem. Phys., 17, 2838 (2015).

27. Y. Song, H. Jing, B. Li, and D. Bai, Chem. Eur. J., 17, 8731 (2011).

28. A. J. Pawlak and M. L. Dietz, Sep. Sci. Technol., 49, 2847 (2014).

29. Y. Song, C. Cheng, amd H. Jing, Chem. Eur. J., 20, 12894 (2014). 
30. A. Kitada, D. Ishikawa, K. Fukami, and K. Murase, J. Electrochem. Soc., 164, H5119 (2017).

31. M. Bühl, R. Ludwig, R. Schurhammer, and G. Wipff, J. Phys. Chem. A, 108, 11463 (2004).

32. A. Kitada, Y. Kang, K. Matsumoto, K. Fukami, R. Hagiwara, and K. Murase, J. Electrochem. Soc., 162, D389 (2015).

33. K. T. Munson, J. Vergara, L. Yu, and T. D. Vaden, J. Phys. Chem. B, 119, 6304 (2015).

34. G. S. Heo and R. A. Bartsch, J. Org. Chem., 47, 3557 (1982).

35. R. Chénevert, A. Rodrigue, P. Beauchesne, and R. Savoie, Can. J. Chem., 62, 2293 (1984)

36. J. Foropoulos Jr. and D. D. DesMarteau, Inorg. Chem., 23, 3720 (1984).

37. W. Xu, E. I. Cooper, and C. A. Angell, J. Phys. Chem. B, 107, 6170 (2003).

38. C. A. Angell, Y. Ansari, and Z. Zhao, Faraday Discuss., 154, 9 (2012).

39. H. K. Kashyap, H. V. R. Annapureddy, F. O. Raineri, and C. J. Margulis, J. Phys. Chem. B, 115, $13212(2011)$.

40. C. A. Angell, K. L. Ngai, G. B. McKenna, P. F. McMillan, and S. W. Martin, Appl. Phys. Rev., 88, 3113 (2000). 
41. K. R. Harris, J. Phys. Chem. B, 114, 9572 (2010). 
Table I. Result of chemical analysis for $\left[\mathrm{H}_{3} \mathrm{O}^{+} \cdot(18 \mathrm{C6})_{2}\right] \mathrm{Tf}_{2} \mathrm{~N}$.

$\begin{array}{llllll}\text { Element } & \mathrm{H}(\%) & \mathrm{C}(\%) & \mathrm{N}(\%) & \mathrm{F}(\%) & \mathrm{S}(\%)\end{array}$

Experimental

6.21

37.59

1.76

13.92

7.75

Calculated

6.17

37.73

1.69

13.78

7.74 
Table II. Diffusion coefficients of $\mathrm{H}_{3} \mathrm{O}^{+}, 18 \mathrm{C6}$, and $\mathrm{Tf}_{2} \mathrm{~N}^{-}$at 60 and $75{ }^{\circ} \mathrm{C}$ for $\left[\mathrm{H}_{3} \mathrm{O}^{+} \cdot(18 \mathrm{C6})_{2}\right] \mathrm{Tf}_{2} \mathrm{~N}$, and at 75 and $85^{\circ} \mathrm{C}$ for $\left[\mathrm{H}_{3} \mathrm{O}^{+} \cdot(18 \mathrm{C6})_{2}\right] \mathrm{Tf}_{2} \mathrm{~N}$.

$$
\text { Temperature } \quad D_{\mathrm{H}_{3} \mathrm{O}^{+}} \quad D_{18 \mathrm{C} 6} \quad D_{\mathrm{Tf}_{2} \mathrm{~N}^{-}}
$$

Mixture

$$
\left[{ }^{\circ} \mathrm{C}\right] \quad\left[10^{-7} \mathrm{~cm}^{2} \mathrm{~s}^{-1}\right] \quad\left[10^{-7} \mathrm{~cm}^{2} \mathrm{~s}^{-1}\right] \quad\left[10^{-7} \mathrm{~cm}^{2} \mathrm{~s}^{-1}\right]
$$

\begin{tabular}{ccccc}
\hline & 60 & 2.4 & 2.7 & 2.6 \\
{$\left[\mathrm{H}_{3} \mathrm{O}^{+} \cdot(18 \mathrm{C} 6)_{2}\right] \mathrm{Tf}_{2} \mathrm{~N}$} & & 3.9 & 4.1 & 4.1 \\
& 75 & 3.6 & 2.4 & 2.6 \\
{$\left[\mathrm{H}_{3} \mathrm{O}^{+} \cdot 18 \mathrm{C} 6\right] \mathrm{Tf}_{2} \mathrm{~N}$} & 75 & & & \\
& 85 & 6.0 & 3.9 & 4.0
\end{tabular}


Table III. VFT fitting parameters for ionic conductivity and viscosity.

\begin{tabular}{ccccc} 
& $\sigma_{0}$ or $\eta_{0}$ & $B$ & $T_{0}[\mathrm{~K}]$ & $B T_{0}[\mathrm{~K}]$ \\
\hline Conductivity & $0.445\left[\mathrm{~S} \mathrm{~cm}^{-1}\right]$ & 1.82 & 189 & 344 \\
Viscosity & $0.199[\mathrm{mPa} \mathrm{s}]$ & 1.51 & 199 & 300
\end{tabular}


Table IV. Viscosities and conductivities of $\left[\mathrm{H}_{3} \mathrm{O}^{+} \cdot(18 \mathrm{C6})_{2}\right] \mathrm{Tf}_{2} \mathrm{~N}$ (this work, at 60 and $75^{\circ} \mathrm{C}$ ), and $\left[\mathrm{H}_{3} \mathrm{O}^{+} \cdot 18 \mathrm{C} 6\right] \mathrm{Tf}_{2} \mathrm{~N}$ (ref. 7 ; at 75 and $85^{\circ} \mathrm{C}$ ).

\begin{tabular}{cccc} 
Mixture & Temperature & Viscosity & Conductivity \\
& {$\left[{ }^{\circ} \mathrm{C}\right]$} & {$[\mathrm{mPa} \mathrm{s}]$} & {$\left[\mathrm{mS} \mathrm{cm}^{-1}\right]$} \\
\hline$\left[\mathrm{H}_{3} \mathrm{O}^{+} \cdot(18 \mathrm{C} 6)_{2}\right] \mathrm{Tf}_{2} \mathrm{~N}$ & 60 & 33.9 & 1.90 \\
& 75 & 20.3 & 2.67 \\
\hline$\left[\mathrm{H}_{3} \mathrm{O}^{+} \cdot 18 \mathrm{C} 6\right] \mathrm{Tf}_{2} \mathrm{~N}$ & 75 & 42.9 & 2.36 \\
& 85 & 32.3 & 3.05
\end{tabular}


Table V. Ionicities and transference numbers of $\left[\mathrm{H}_{3} \mathrm{O}^{+} \cdot(18 \mathrm{C6})_{2}\right] \mathrm{Tf}_{2} \mathrm{~N}$ at 60 and

$75^{\circ} \mathrm{C}$.

Ionicity

Transference number

Temperature $\left[{ }^{\circ} \mathrm{C}\right]$

$$
\Lambda_{\mathrm{imp}} / \Lambda_{\mathrm{NMR}} \quad t_{\mathrm{H}_{3} \mathrm{O}^{+}}
$$

60

0.78

0.48

75

0.88

0.49 
Figure 1. DSC curves for $\left[\mathrm{H}_{3} \mathrm{O}^{+} \cdot(18 \mathrm{C} 6)_{2}\right] \mathrm{Tf}_{2} \mathrm{~N}$.

Figure 2. (a) Raman spectra between 700 and $900 \mathrm{~cm}^{-1}$ of $\left[\mathrm{H}_{3} \mathrm{O}^{+} \cdot(18 \mathrm{C} 6)_{2}\right] \mathrm{Tf}_{2} \mathrm{~N}$ (at room temperature), $\left[\mathrm{H}_{3} \mathrm{O}^{+} \cdot 18 \mathrm{C} 6\right] \mathrm{Tf}_{2} \mathrm{~N}$ (at $75^{\circ} \mathrm{C}$ ), and pure $18 \mathrm{C} 6\left(\right.$ at $60{ }^{\circ} \mathrm{C}$ ), and (b) Raman spectra (red curves) and Gaussian fits (blue curves) between 760 and $900 \mathrm{~cm}^{-1}$ for $\left[\mathrm{H}_{3} \mathrm{O}^{+} \cdot 18 \mathrm{C} 6\right] \mathrm{Tf}_{2} \mathrm{~N}$ (upper panel) and $\left[\mathrm{H}_{3} \mathrm{O}^{+} \cdot(18 \mathrm{C} 6)_{2}\right] \mathrm{Tf}_{2} \mathrm{~N}($ lower panel).

Figure 3. IR spectra of $\left.\mathrm{H}_{3} \mathrm{O}^{+} \cdot(18 \mathrm{C} 6)_{2}\right] \mathrm{Tf}_{2} \mathrm{~N},\left[\mathrm{H}_{3} \mathrm{O}^{+} \cdot 18 \mathrm{C} 6\right] \mathrm{Tf}_{2} \mathrm{~N}$, and pure $18 \mathrm{C} 6$ measured at room temperature: (a) high-wavenumber region from 1600 to $4000 \mathrm{~cm}^{-1}$ and (b) lowwavenumber region from 800 to $1400 \mathrm{~cm}^{-1}$.

Figure 4. (a) ${ }^{1} \mathrm{H}$, (b) ${ }^{13} \mathrm{C}$, and (c) ${ }^{19} \mathrm{~F}$ NMR spectra of $\left[\mathrm{H}_{3} \mathrm{O}^{+} \cdot(18 \mathrm{C} 6)_{2}\right] \mathrm{Tf}_{2} \mathrm{~N}$ at $60{ }^{\circ} \mathrm{C}$.

Figure 5. Plots and best-fit lines of echo signal attenuation on the basis of the Stejskal equation for $18 \mathrm{C} 6$ (red circles), $\mathrm{Tf}_{2} \mathrm{~N}^{-}$(blue circles), and $\mathrm{H}_{3} \mathrm{O}^{+}$(black circles) at (a) $60{ }^{\circ} \mathrm{C}$ and (b) $75^{\circ} \mathrm{C}$. 
Figure 6. Walden plots for $\left[\mathrm{H}_{3} \mathrm{O}^{+} \cdot(18 \mathrm{C} 6)_{2}\right] \mathrm{Tf}_{2} \mathrm{~N}$ (squares) and $\left[\mathrm{H}_{3} \mathrm{O}^{+} \cdot 18 \mathrm{C} 6\right] \mathrm{Tf}_{2} \mathrm{~N}$

(triangles; ref. 7).

Figure 7. Plots and best-fit lines of the temperature dependence of ionic conductivities

(open circles) and viscosities (closed circles) of $\left[\mathrm{H}_{3} \mathrm{O}^{+} \cdot(18 \mathrm{C} 6)_{2}\right] \mathrm{Tf}_{2} \mathrm{~N}$.

Figure 8. TGA curves for (a) $\left[\mathrm{H}_{3} \mathrm{O}^{+} \cdot(18 \mathrm{C} 6)_{2}\right] \mathrm{Tf}_{2} \mathrm{~N}$, (b) $\left[\mathrm{H}_{3} \mathrm{O}^{+} \cdot 18 \mathrm{C} 6\right] \mathrm{Tf}_{2} \mathrm{~N}$, (c) pure $18 \mathrm{C} 6$, and (d) $\mathrm{HTf}_{2} \mathrm{~N} \cdot \mathrm{H}_{2} \mathrm{O}$. 


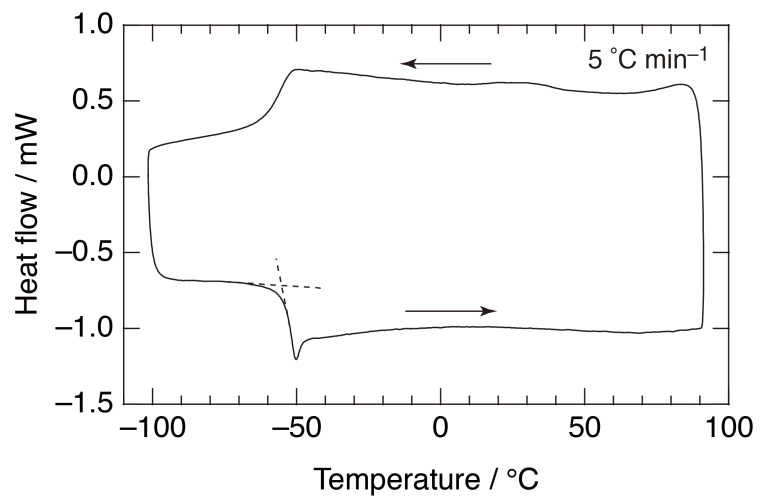



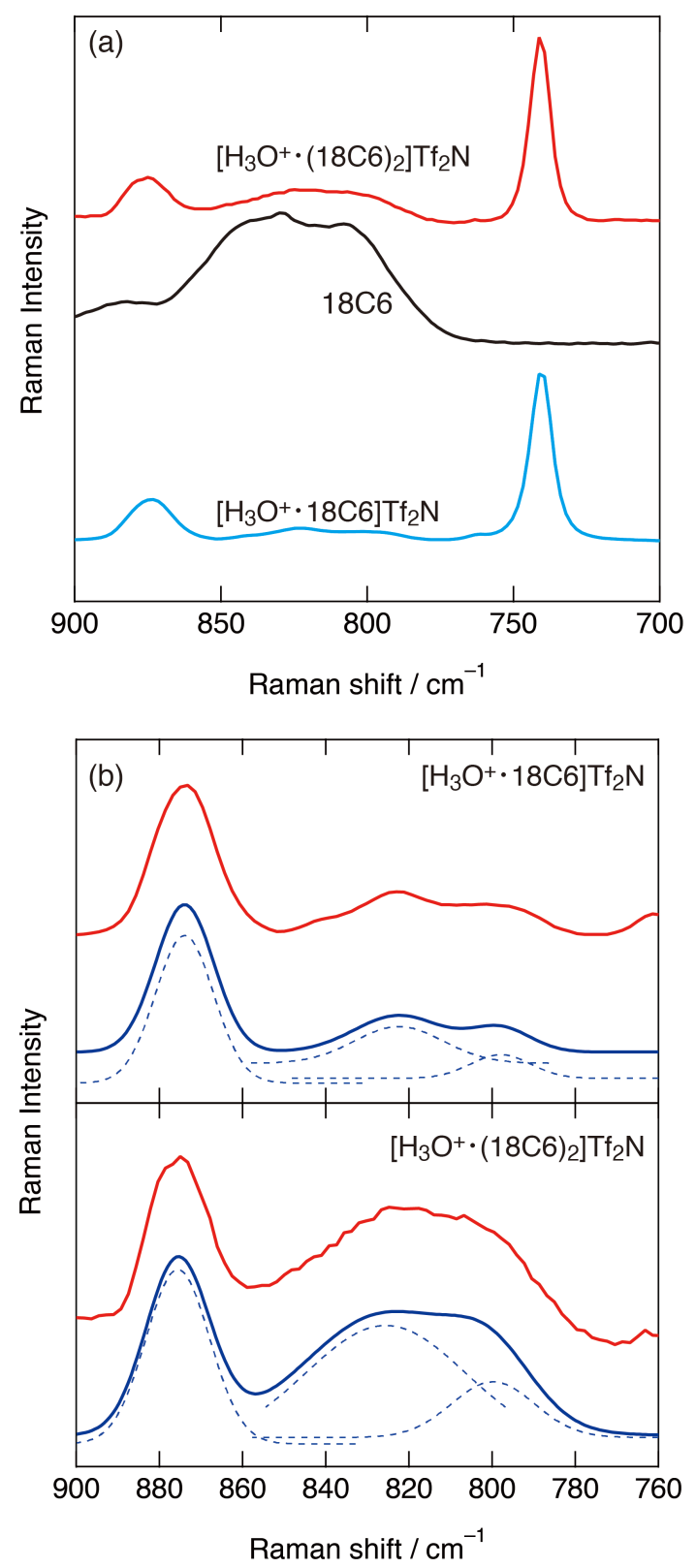
(a)

(b)

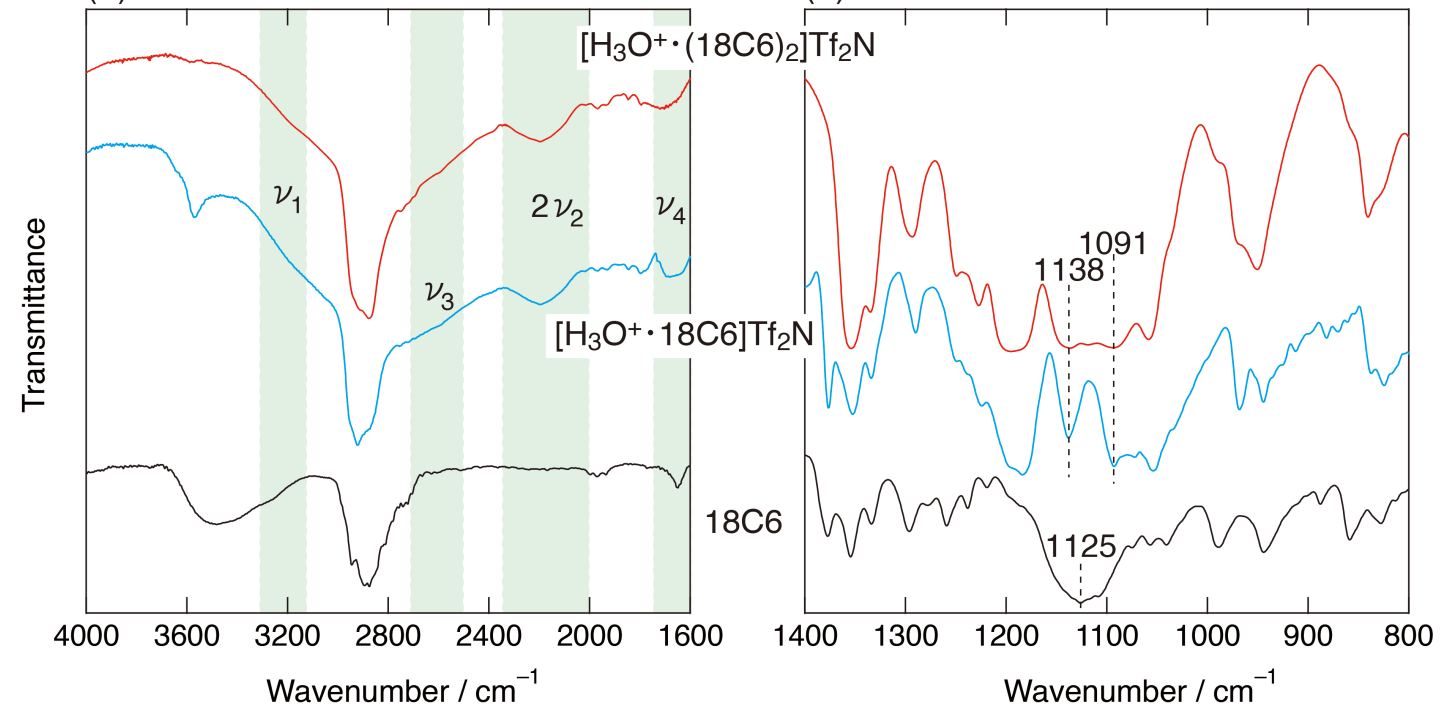



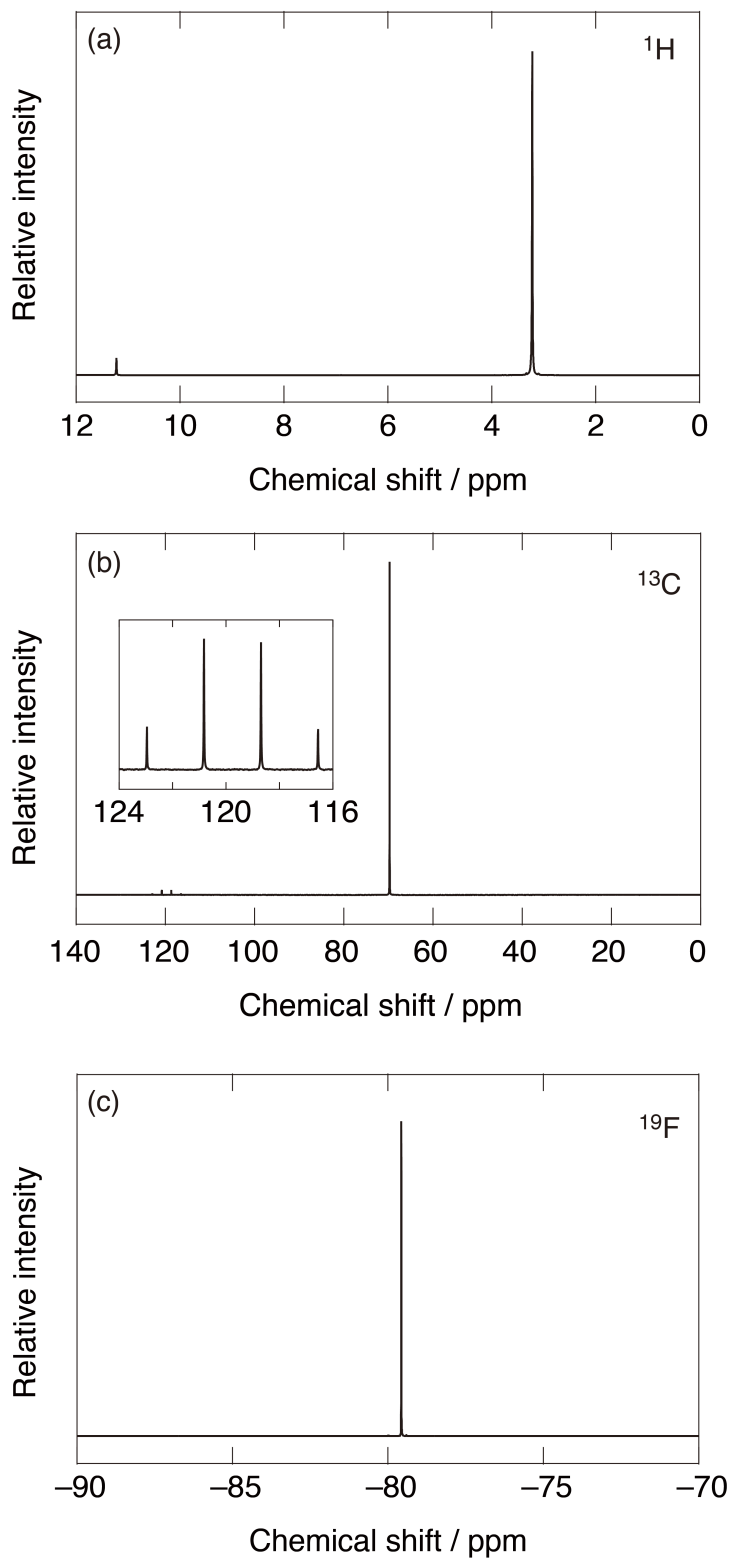

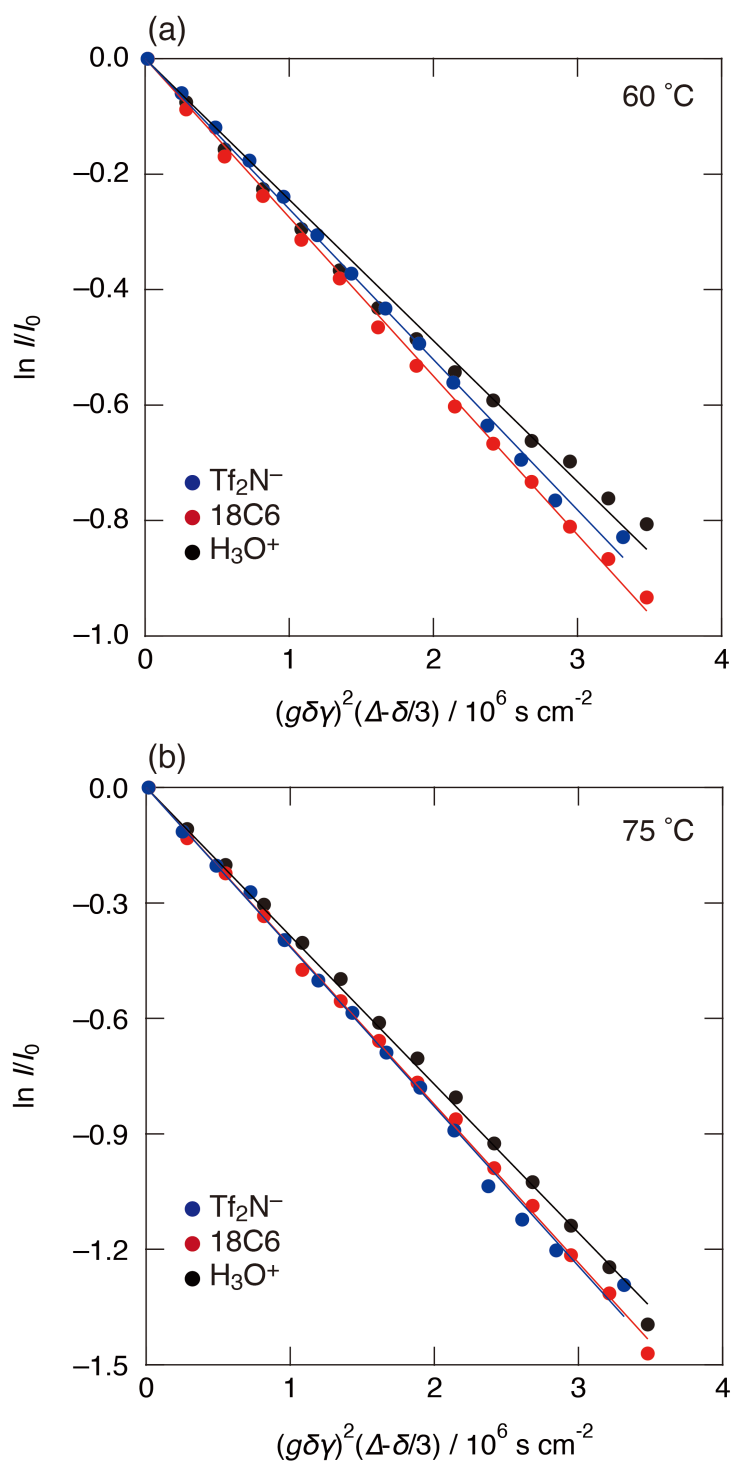


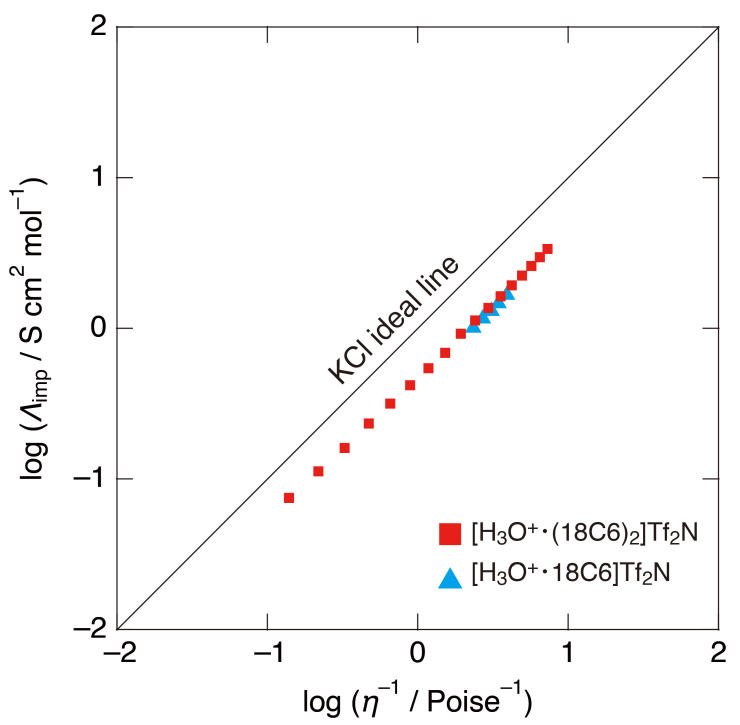


Temperature $/{ }^{\circ} \mathrm{C}$

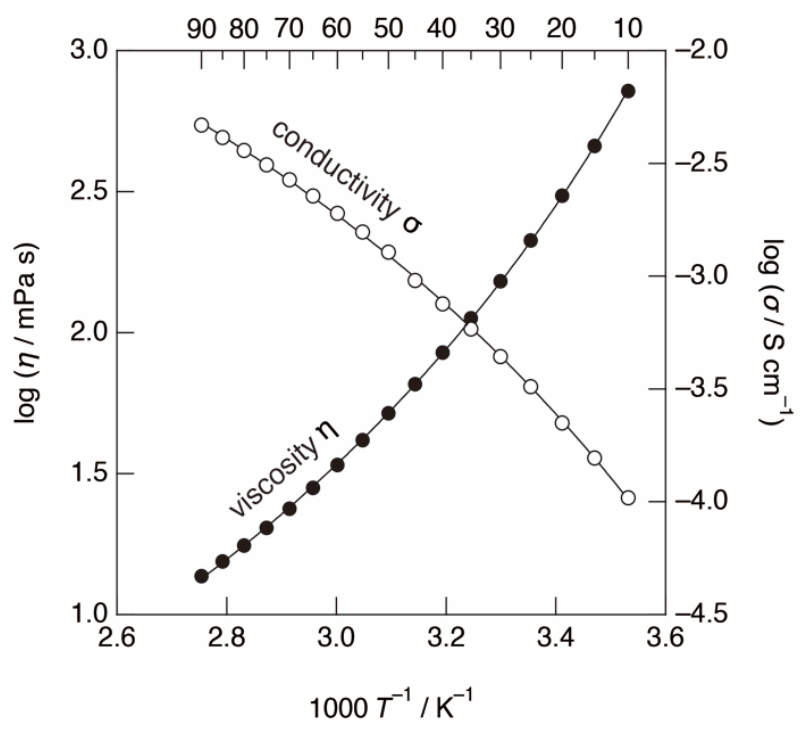




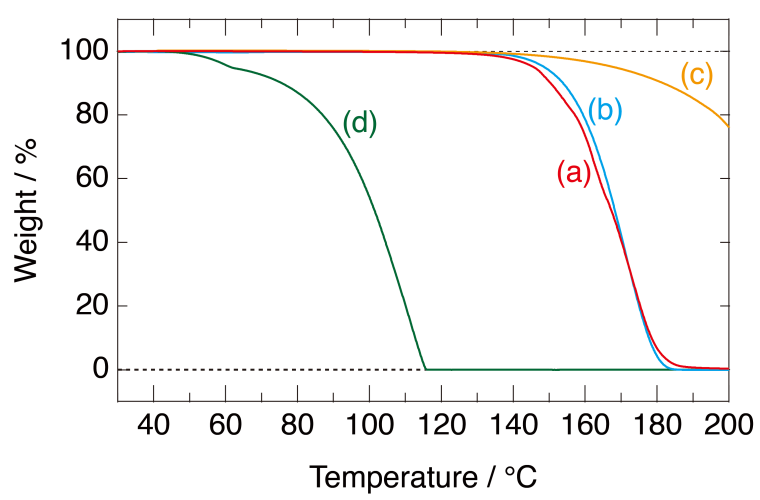

